\title{
PROBLEMS OF RELIABILITY ASSESSMENT OF IMPACT EXCITATION SYSTEMS OF HYDRAULIC HAMMERS
}

\section{PROBLEMY OCENY NIEZAWODNOŚCI UKLADÓW WYMUSZENIA UDAROWEGO MLOTÓW HYDRAULICZNYCH}

\author{
Marek Sokolski \\ Wroclaw University of Science and Technology \\ Politechnika Wrocławska
}

\begin{abstract}
The topological structures of impact excitation systems in hydraulic hammers were characterized. Basic problems of reliability prediction of elements of these systems are defined. The main factors determining the reliability of working systems were identified. As an application example, the research results of small-sized hydraulic hammers are presented for which the statistical distributions of the maximum values of stresses generated in systems "beater-tool" are estimated. On this basis, the reliability prediction of impact excitation systems of these hammers was made.
\end{abstract}

Keywords: hydraulic hammers, impact excitation systems, reliability

Streszczenie: Scharakteryzowano struktury topologiczne układów wymuszenia udarowego stosowanych $w$ mtotach hydraulicznych. Zdefiniowano podstawowe problemy zwiazane z prognozowaniem niezawodności elementów tych ukladów. Zidentyfikowano główne czynniki determinujace niezawodność układów roboczych. Jako przykład obliczeniowy przedstawiono wyniki badań małogabarytowych mlotów hydraulicznych, dla których wyznaczono rozkłady statystyczne maksymalnych wartości naprężeń generowanych w uktadzie „,bijak-narzędzie”. $\mathrm{Na}$ tej podstawie dokonano prognozy niezawodności uktadów wymuszenia udarowego tych młotów.

Stowa kluczowe: mtoty hydrauliczne, uklady wymuszenia udarowego, niezawodność 
Problems of reliability assessment of impact excitation systems of hydraulic... Problemy oceny niezawodności układów wymuszenia udarowego młotów...

\section{PROBLEMS OF RELIABILITY ASSESSMENT OF IMPACT EXCITATION SYSTEMS OF HYDRAULIC HAMMERS}

\section{Introduction}

Hydraulic hammers are used today in many areas of industrial activity - including mining and quarrying, civil engineering and metallurgy. In many cases, the mining process by means of hammers is safer than the use of explosives - e.g. in tunneling or demolition works in urban areas [8].

Wide range of applications and varied operating conditions of hydraulic hammers create high demands on durability and reliability. This applies in particular to the main working systems and their elements, i.e. to hydraulic excitation systems and impact excitation systems. Repairs of elements of these systems in mining conditions are very difficult and expensive, and in many cases they are practically impossible to be carried out [8].

In this context, a need arises to formulate basic research problems, to identify the factors which have influence on the reliability of elements impact excitation system as well as to develop a method of reliability assessment and prediction. However, modern hydraulic hammers are so complex objects that "intuitive" approach to these issues may not be sufficient.

In the relevant literature (e.g $[4,5,6])$ there are various definitions of the reliability of mechanical objects by using such terms as "availability", "resistance to failure", "ability", "meet the requirements", "maintainability" etc. Apart from this, the reliability is treated in deterministic or probabilistic approach.

In this article, the relevant definition is used, according to which the reliability of the force of impact system is determined by the probability of failure-free operation, i.e. by the probability of keeping an acceptable level of ability (without significant damages) of elements of this system - under random existing workloads. For such formulated task, the method for predicting the reliability of elements of impact excitation systems was proposed. This method is based on the analysis of interaction between random variable workloads and random variable resistance of impact zone. As an application example, the results of the reliability assessment of impact excitation systems of small-sized hydraulic hammers for dynamic assisted tools in ploughs for mining thin coal seams are presented.

\section{Topological structures of impact excitation systems}

In contemporary hydraulic hammers various solutions of impact excitation system are used, under which one can distinguish the following basic topological structure $[2,8]$ :

- the so-called projectile systems (Fig. 1a) in which there is one element which performs the functions of a beater and a tool, 
- the beater systems, in which functions of beater and tools are separated, wherein the are existing the systems with direct mechanical "steel-on-steel" blows (Fig. 1b) and the systems with intermediate "steel - on - medium - on - metal" blows (Fig. 1c).

a)

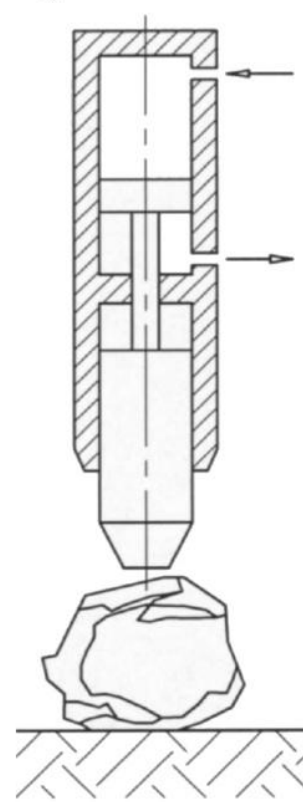

b)

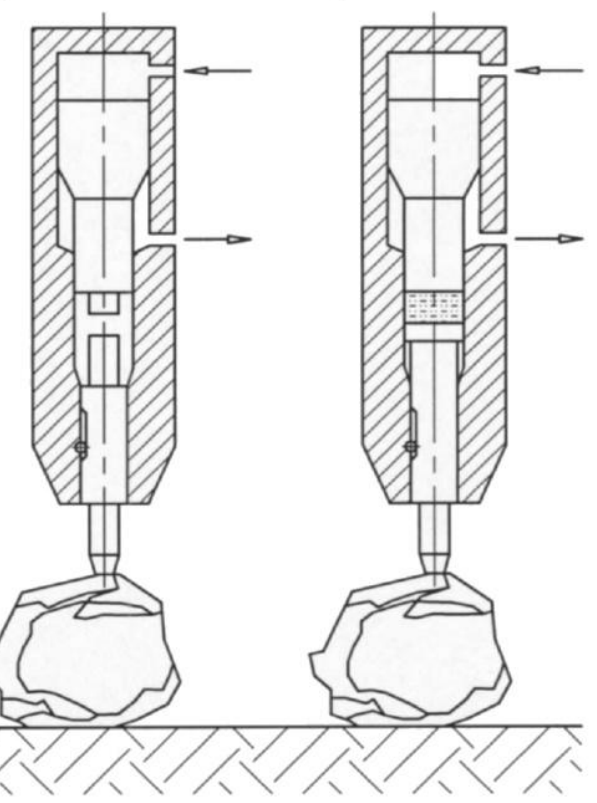

Fig. 1. Basic topological structures of impact excitation systems in hydraulic hammers

In the systems with projectile structure, the working process - e.g. rock mining, demolition or driving of the pile foundation - is done by a direct blows of the tool. Although the advantage of this solution is the possibility of using high velocity and impact energy, however the essential disadvantage is the fact that the tool is not initially pressed against the surface of the object (e.g. to rock to be broken). A consequence of this, the phenomenon of strong energy recoil occurs, which reduces the effective energy flow (i.e. reduces the efficiency of mining) and causes considerable dynamic load in boom system. For these reasons, the projectile type hydraulic hammers are not in generally used in mining, but they are applied in some cases in civil engineering, e.g. for removal of road surfaces or trenching in rocky ground.

The essence of impact excitation systems of hydraulic hammers with direct mechanical impact (Fig. 1b) is to generate cyclical blows in the working system "steel-on-steel", which has not any additional intermediate elements. 
Problems of reliability assessment of impact excitation systems of hydraulic... Problemy oceny niezawodności układów wymuszenia udarowego młotów...

This kind of structure of impact systems has many advantages, among which the particularly important feature is the ability to held the tool against item (rock) to be broken, thereby reducing the adverse effect of the recoil energy of the impact.

The beater systems with an additional intermediate element - especially those which use the hydraulic medium ("HEFTI" hammers developed by Joy Mfg. Co.) has many valuable advantages. The basic advantage is the ability to use high-speed impact (at approx. $30 \mathrm{~m} / \mathrm{s}$ ), which is unacceptable in the excitation systems with direct mechanical "steel-on-steel" blows.

However, despite this, the conventional systems based on direct mechanical "steelon-steel" blows are most widely applied group of impact excitation systems in hydraulic hammers.

The more comprehensive analysis of the basic topological structures of impact excitation systems of hydraulic hammers is presented in $[2,8]$.

\section{Research problems}

Reliability of impact excitation systems and their main components: beaters and tools can be treated in technical or economic terms.

In this article, the technical reliability of impact excitation systems is considered, which is defined as the probability of failure-free operation, i.e. without any damage that could cause loss the ability of these system or their components to function under given conditions.

In this sense, the reliability of the impact excitation system is understood as the probability of keeping the main functional features of its components - for example, the probability that the tool strength is not exceeded and there are not chipping of impact surface, breakage or bending of the shank, etc.

Another issue - but not considered in the article - is, however, reliability formulated in economic terms, which takes account of the efficacy and costeffectiveness of tool recondition (repair), if certain damage has occurred.

In multi-aspect approach to the technical reliability of the working systems of hydraulic hammers, there are many research problems, among which, in the author's opinion, these are particularly important:

- identification of critical areas in the context of degradation and failures of impact excitation systems,

- identification of qualitative and quantitative structures of damage of impact excitation systems of hydraulic hammers in the conditions of Polish mines and quarries,

- estimation of statistical distributions of maximum values of loads (stresses) in the critical areas of components of impact excitation systems,

- estimation of statistical distributions of basic parameters of the strength of components of impact excitation systems of hydraulic hammers,

- development and experimental verification of methods to assess the reliability of existing impact excitation systems as well as methods to predict the reliability of systems to be made. 


\section{Basic factors which influence the reliability of impact excitation systems of hydraulic hammers}

The most common causes of inability of impact excitation systems of hydraulic hammers are failures of tools as a result of excessive workloads, which - under certain conditions - cause stress concentration and exceeding ultimate or fatigue material strength.

Susceptibility to failures of hammer tools is determined by different structural, technological and operational factors. Typical destructive factors of a design nature are all kinds of constructional notches (e.g. the grooves under retainer pins of tools), whereas the factors of a technological nature can be e.g. materials with inadequate microstructure or improper thermo - chemical treatment of tools.

The basic destructive factors resulting from operation are, inter alia: [8]:

- impact nature of working loads which achieve significant amplitudes,

- additional non axial external loads occurred in some extreme states, e.g. when the tool is using for prying rock lumps or when it is working at incorrect, too acute setting angle,

- striking the free tool which is not properly preloaded (the so-called blank firing),

- negative temperature causing a decrease in resistance to cracking and fatigue strength of the material tools,

- too high working temperature (in steelworks or foundries),

- corrosion due to aggressive environmental influences (humidity, salinity),

- insufficient lubrication at the tool shank in the cylinder of the hammer and retainer pins.

Damages of hammer tools may be gradual/wear (fatigue, creep, corrosion, ageing, etc.) or they are of a sudden/catastrophic nature (curvature, crack or fracture of the shaft, seizure, chipping working tip, etc.). Apart from this, damages of tools can occur as:

- partially damages (destruction of some fragments of tool), e. g. damage to the retainer pin, partial wear of the working tip) under which the tool can still be conditionally operated but with less efficiency,

- total damage (damage to a larger zone), for example fracture of tool shank), which qualify the tool to replacement.

Degradation processes of hammer tools are usually occurred in a few specific zones shown in Fig. 2. Typical forms of this degradation are mainly: a so-called mushrooming of the surface of rear part of tool (place where the beater strikes), fracture of shank, damage of the retainer pin, seizing of groove for retainer pin, mushrooming and chipping of the tip $[1,8,10]$. 
Problems of reliability assessment of impact excitation systems of hydraulic... Problemy oceny niezawodności układów wymuszenia udarowego młotów...

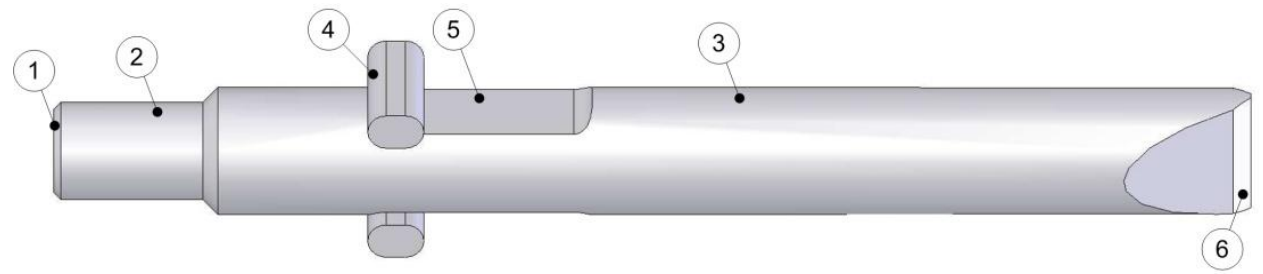

Fig. 2. Typical zones of tool failures in hydraulic hammers: 1 -impact zone, 2 -rear end, 3 -shank, 4 -retainer pin, 5 -groove for retainer pin, 5 - working tip

Among the operational factors affecting the durability and reliability of the tools of hydraulic hammers, the proper maintenance plays a special role. This includes preventive and precautionary actions (periodic technical inspections), carried out for the preservation of functional properties of hydraulic hammers.

Qualifications and experience of operators as well as their individual ability to adapt to difficult working conditions are also important.

One of the attributes of the working process of hydraulic hammer is a high level of noise that, especially in a confined area (e.g. in underground mine), can be a real source of acoustic hazards and cause inter alia: impaired coordination, distraction, stress and faster fatigue of operators.

Whereas, typical examples of the effects of the destructive activities of operators are damages of the retainer pins of tools (plastic deformations or local cracks) arising as a result of striking the tool not properly pressed against rock (blank firing). Such cases can happen especially when mining hard rocks that under the influence of strokes are suddenly broken and the tool is moved forward until it is stopped on the retainer pin. Experienced and properly concentrated operator is able to successfully predict the moment when the rock breaks (on the basis of changes of sound timbre of strokes during operation of the hammer) and he can stop striking at the right time. In contrast, an inexperienced or tired operator can not react in time properly and cause damage to the retainer pin of tool.

Another example of operators errors is prolonger striking the tool above the permissible period (in general, no more than 20-30 seconds). In such cases, the excessive heat is generated and mushrooming the rear end of the tool can occur. This is, in generally, classified as an irreparable damage, even in the service workshop $[8,10]$.

\section{Reliability as the resistance to working loads under impact excitation}

The technical reliability of impact excitation systems can be analyzed in particular in relation to specific areas of working tools where degradation occurs.

One of such specific critical areas is the impact zone where the load reaches very high values. Because of stress concentration on the impact surface, it can relatively easily lead to exceeding the yield stress, or even its ultimate strength. In these circumstances, degradation occurs and the tool loses its ability to keep functioning (meeting specified requirements). 
From the classical contact mechanics applied to static problems (e.g. from Hertzian theory) it results, that the greatest values of the von Mises stress in the contact zone occur on the contour of the area, and they are larger by about $15 \%$ than the values in the centre of this zone [3]. Numerical analysis of impact excitation process in a system "beater - tool", carried out by the author $([8,9])$ show that in some cases, the von Mises equivalent stress in the contact zone can be almost three times higher than it is according to the classical static theory based on the Hertzian model. However - in analogy to the static contact mechanics - the maximum values of equivalent stress appear on the contour of impact zone and they are on average about $20 \%$ higher than in the centre of this zone.

This caused a degradation of the rear end of the tool which has a typical shape of the so-called mushrooming $[8,10]$.

In this context, evaluation and forecasting of the reliability of the impact zone should take into account the fact that, in real operating conditions, both working loads and strength of components of impact excitation systems are random variables.

Having regard to this, the reliability $R$ of the impact excitation system of hydraulic hammer is defined as the probability of failure-free operation - i.e. as the probability that the random varying equivalent von Mises stress $\sigma$ in the impact zone will not exceed the level of a random varying material strength of tool - that is:

$$
R=P(Z>\sigma)=\int_{-\infty}^{\infty} f_{Z}(Z)\left[\int_{-\infty}^{Z} f_{\sigma}(\sigma) d \sigma\right] d Z
$$

where:

$\sigma, f_{\sigma}(\sigma)$ - maximal value and probability density function of equivalent stress, respectively,

$Z, f_{Z}(Z)$ - strength and probability density function of material strength of elements of impact excitation system of hydraulic hammer, respectively.

Thus the expression (1) defines the reliability $R$ of the impact excitation system in a "constructional" approach as the ability of hammer tool to resist impact loading with an acceptable degree of probability.

The efficient solution of so defined research problem requires detailed knowledge of statistical distributions of maximum values of equivalent stress as well as statistical distributions of material strength in the impact zone. The relevant application example for predicting the reliability is shown below.

\section{Application example - reliability prediction of impact excitation systems of small-size hydraulic hammers}

As an application example of the proposed method of reliability assessment/prediction the research results of small-sized hydraulic hammers are presented. This research was carried out on the special test stand in the laboratory condition at the Faculty of Mechanical Engineering of Wroclaw University of Science and Technology. 
Problems of reliability assessment of impact excitation systems of hydraulic... Problemy oceny niezawodności układów wymuszenia udarowego młotów...

As the research objects the series of type of small-size hydraulic hammers MH1-MH7 (Fig. 3) developed by CMG "Komag" in Gliwice (Poland) were used. These hammers are designed to support the working process of dynamical ploughs for thin seams coal mining.
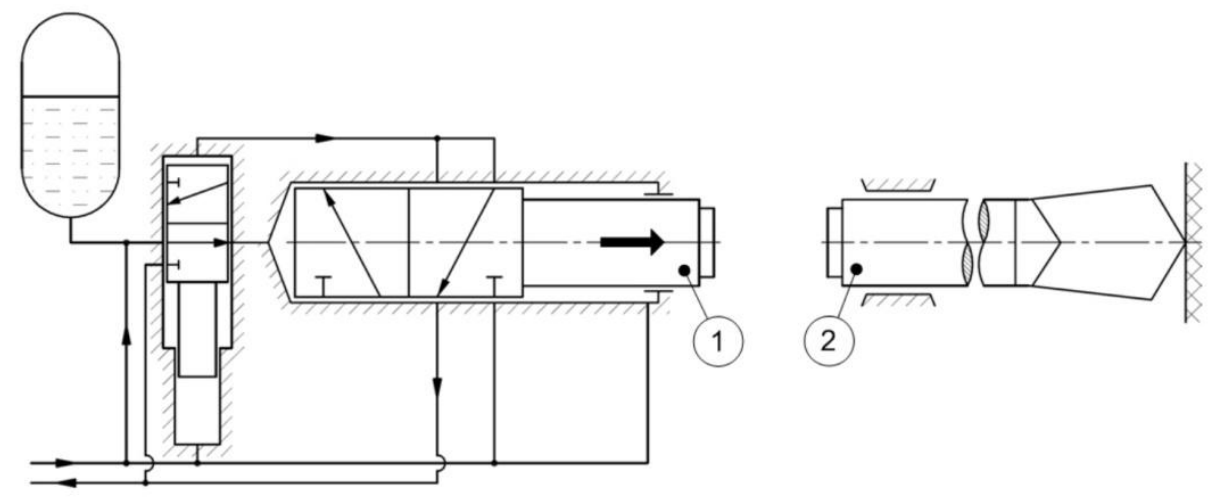

Fig. 3. Scheme of the small-size hammer: 1 - beater, 2 -tool

The research was carried out in different variants of supply pressure $p$, amplitude of free piston stroke $s_{\mathrm{b} 0}$ as well as capacity of hydraulic accumulator $V_{\mathrm{a}}$. supporting working stroke of hammers. During these tests, the stresses generated in impact excitation systems were measured and recorded. Exemplary histograms of maximum stress values for the 2 variants, i.e. for:

- nominal values of operating parameters: $p=16 \mathrm{MPa}, V_{\mathrm{a}}=0,8 \mathrm{dm}^{3}$;

- extreme values of operating parameters: $p=20 \mathrm{MPa}, V_{\mathrm{a}}=5,0 \mathrm{dm}^{3}$ : are presented in Fig. 4.
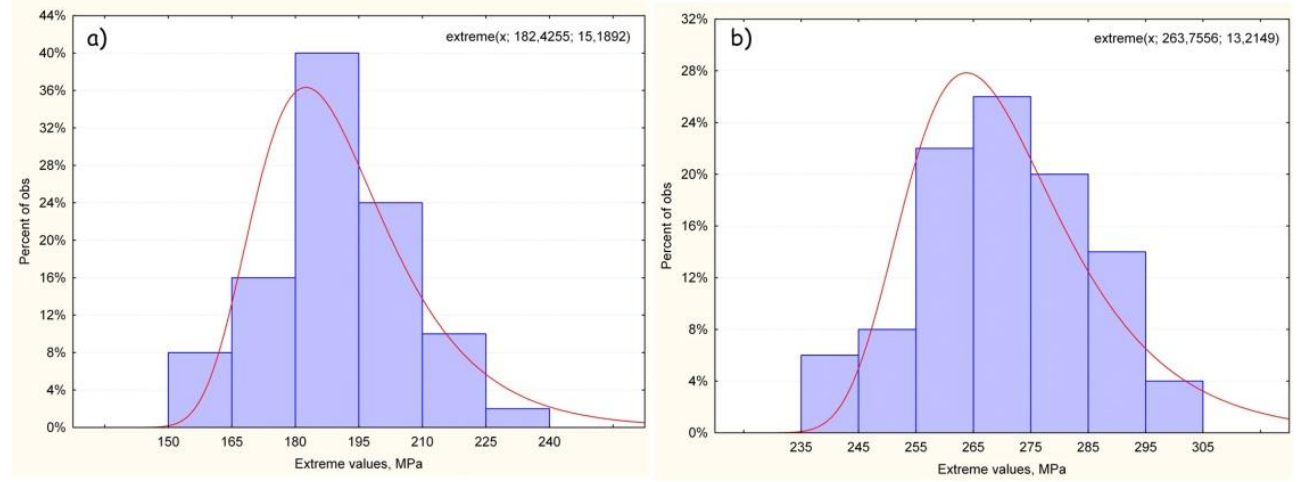

Fig. 4. Histograms of maximum stress values in the impact zone:

a) for nominal values of operating parameters,

b) for extreme values of operating parameters

Then based on a detailed analysis of results, the estimation of parameters of statistical distributions of maximum impact stress has been made - having regard to three basic asymptotic distributions: Gumbel, Frechet and Weibull. 
The numerical values of parameters of these distributions was estimated by maximum likelihood method using the software package Statistica.

It has been shown (based on the Kolmogorov-Smirnov test) that the best suitable model for the experimental data is the Gumbel Extreme Value Distribution which can be expressed in a general form as follows:

$$
f(\sigma)=f_{G}\left(\sigma_{\max }\right)=\frac{1}{b} \exp \left\{-\frac{\sigma_{\max }-a}{b}-\exp \left(-\frac{\sigma_{\max }-a}{b}\right)\right\}
$$

where: $a$-threshold (location) parameter, $b$ - scale parameter.

With regard to the material strength (load capacity) of components of impact system, the assumption is accepted that this material feature is a random variable with normal distribution which basic parameters are as follows:

- expected value $m_{\mathrm{Z}}$ is equal to the nominal yield strength $\sigma_{\mathrm{y}}\left(\right.$ e.g. $\left.m_{\mathrm{Z}}=\sigma_{\mathrm{y}}\right)$,

- standard deviation $\mathrm{s}_{\mathrm{Z}}$ is alternatively equal to $5 \%$ or to $10 \%$ of this yield strength $\sigma_{\mathrm{y}}$ (coefficient of variation $\delta=s_{\mathrm{z}} / \sigma_{\mathrm{y}}$ is equal to $\delta=0.05$ or to $\delta=0.10$, respectively).

The coefficient of strength variation $\delta=s_{z} / \sigma_{y}$ takes into account the random material and technological imperfections (structural heterogeneity, errors thermal or thermo-chemical treatment) as well as varying environmental conditions (negative temperature, moisture and salinity caused corrosion, etc.) which affect the reduction of material strength.

In order to generalize the results of calculations, the safety factor $X=\sigma_{\mathrm{y}} / m_{\sigma}$ was introduced and defined as the ratio of yield point $\sigma_{\mathrm{y}}$ to the expected value $m_{\sigma}$ of stress. On this basis, the failure probability $P_{\text {fail }}=P(Z<\sigma)$ and reliability $R=P(Z \geq \sigma)$ of impact excitation systems of tested hydraulic hammers were estimated. Sample results are shown in Fig. 5.

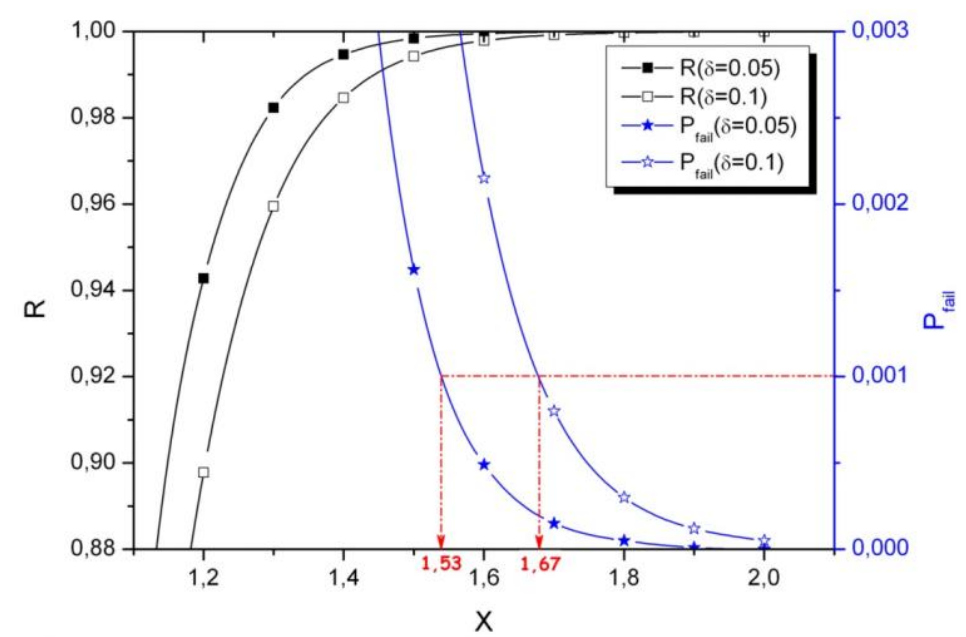

Fig. 5. Reliability $R$ and failure probability $P_{\text {fail }}$ of impact excitation systems of tested small-size hydraulic hammers 
Problems of reliability assessment of impact excitation systems of hydraulic... Problemy oceny niezawodności układów wymuszenia udarowego młotów...

If the acceptable failure probability of impact zone is accepted as $P_{\text {fail }} \leq 0.001$, then the safety factor related to the yield strength shall be not less than $X_{\min }=1.5 \div 1.7$ (Fig. 5). Whereby, the higher values of required safety factor $X_{\min }$ refer to steels having greater extent of variability in the yield strength (coefficient of variation $\delta=0.10$ ).

If the failure probability $P_{\text {fail }} \leq 0.01$ and reliability $\mathrm{R} \geq 0.99$ as a condition of failure-free operation of impact excitation system are accepted, then the following conclusions are:

- For the nominal supply parameters of tested hammers: components of impact excitation systems should be made of steel with a yield strength $\sigma_{\mathrm{y}}$ of not less than the following values (taking into account the parameters of the Gumbel Extreme Value Distribution of stress - Fig. 4a):

$$
\sigma_{\mathrm{y}(\min )} \geq X_{\min } \cdot m_{\sigma} \cong(1.5 \div 1.7) \cdot 191.2 \cong 270 \div 235 \mathrm{MPa}
$$

- For the extremal supply parameters of tested hammers: components of impact excitation systems should be made of steel with a yield strength $\sigma_{\mathrm{y}}$ of not less than the following values (taking into account the parameters of the Gumbel Extreme Value Distribution of stress - Fig. 4b):

$$
\sigma_{\mathrm{y}(\min )} \geq X_{\min } \cdot m_{\sigma} \cong(1.5 \div 1.7) \cdot 271.4 \cong 410 \div 460 \mathrm{MPa}
$$

It was considered in those calculations, that the expected value $m_{\sigma}$ of the Gumbel Extreme Value Distribution is equal to $m_{\sigma}=a+\gamma \cdot b \approx 0.577 \cdot b$ (where $a, b$ parameters of the Gumbel distribution, $\gamma$ - Euler's constant).

\section{Summary}

Reliability of impact excitation systems of hydraulic hammers is determined by a variety of causes of constructional, technological and operational nature.

The presented method of reliability prediction is based on an assessment of the resistance of "beater - tool" system to impact working loads while keeping the required safety margin. The method takes into account the random nature of impact stresses as well as random nature of the material strength of elements of these systems. The parameters of the statistical distributions of both of these quantities are experimentally estimated.

As an example application, the reliability assessment of impact excitation systems of small-sized hydraulic hammers designed to support the working process of dynamical coal ploughs is presented. 


\section{References}

[1] Bauer E.E.: Contech Mining Application Manual. Consolidated Technologies Corp., Mining Division, Denver (sine anno).

[2] Grantmyre I., Hawkes I., High - Energy Impact Rockbreaking, The Canadian Mining and Metallurgical Bulletin. August 1975, pp. 1-8.

[3] Johnson K.L: Contact Mechanics, Cambridge University Press, Cambridge, 2003.

[4] Kececioglu D.: Reliability Engineering Handbook, vol. 1, DEStech Publications, Inc., Lancaster, PA, USA, 2002.

[5] Migdalski J. (ed.): Realibility Handbook. Mathematical fundamentals (in Polish). Wyd. „WEMA”, Warszawa 1982.

[6] Nowakowski T.: Reliability of Logistic Systems (in Polish). Oficyna Wydawnicza Politechniki Wroclawskiej, Wrocław, 2011.

[7] Smalko Z.: Selected problems of description and estimation of durability. Journal of KONBiN 1(4) 2008, pp. 321-326.

[8] Sokolski M.: Fundamentals of Synthesis of Characteristics of Hydraulic Hammers (in Polish). Oficyna Wydawnicza Politechniki Wroclawskiej, Wrocław, 2013.

[9] Sokolski M., Sokolski P.M.: Strength estimation of the impact zone - a critical area of the tools of the hydraulic hammers. Archives of Civil and Mechanical Engineering, 2016, vol. 16, nr 4, pp. 767-776.

[10] TB Series Hydraulic Breakers. Owner's Manual. Breaker Technology Inc., Thornbury, ON, Canada 2013.

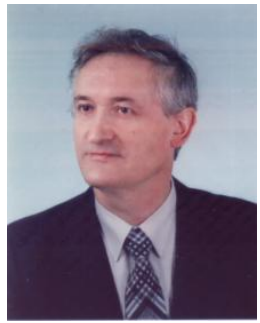

Marek Sokolski, Ph.D. Assistant Professor, Wroclaw University of Science and Technology, Faculty of Mechanical Engineering, Department of Maintenance and Operation of Logistic, Transportation and Hydraulic Systems. Doctoral dissertation on the identification of energy and force characteristics of impact rock breaking.Habilitation thesis on the fundamentals of synthesis of performance characteristics of hydraulic hammers. Areas of scientific interest: heavy engineering and mining machinery, technical diagnostics and reliability, technical infrastructure of storage systems, materials handling, internal transport. 
Problems of reliability assessment of impact excitation systems of hydraulic... Problemy oceny niezawodności układów wymuszenia udarowego młotów...

\section{PROBLEMY OCENY NIEZAWODNOŚCI UKLADÓW WYMUSZENIA UDAROWEGO MLOTÓW HYDRAULICZNYCH}

\section{Wstęp}

Młoty hydrauliczne są stosowane współcześnie w wielu obszarach działalności przemysłowej - m.in. w górnictwie i skalnictwie, inżynierii lądowej i budownictwie oraz hutnictwie. W wielu przypadkach urabiania za pomocą młotów jest bezpieczniejsze od stosowania materiałów wybuchowych - np. przy drążeniu tuneli lub w pracach wyburzeniowych na terenach zurbanizowanych [8].

Szerokie spektrum zastosowań i zróżnicowane warunki eksploatacji młotów hydraulicznych stawiają jednocześnie wysokie wymagania między innymi w stosunku trwałości i niezawodności. Odnosi się to szczególnie do elementów układów roboczych, tj. układów wymuszenia hydraulicznego oraz układów wymuszenia udarowego. Naprawa tych elementów w warunkach kopalnianych jest bowiem bardzo kłopotliwa i kosztowna, a w wielu przypadkach - praktycznie niemożliwa [8].

W tym kontekście pojawia się potrzeba zdefiniowania podstawowych problemów badawczych, identyfikacji czynników wpływających na niezawodność elementów układów wymuszenia udarowego oraz opracowania metody prognozowania niezawodności. Współczesne młoty hydrauliczne są obiektami na tyle złożonymi, że „intuicyjne” podejście do powyższych zagadnień może być niewystarczające.

W literaturze przedmiotu (m.in. [4,5,6]) stosowane są różne określenia niezawodności obiektów mechanicznych przy wykorzystaniu takich pojęć jak „gotowość”, „nieuszkadzalność”, „zdatność”, „spełnienie wymagań”, „obsługiwalność” itp. Niezależnie od tego, niezawodność jest rozpatrywana w ujęciu deterministycznym lub w kategoriach probabilistycznych.

W niniejszym artykule przyjęto definicję, zgodnie z którą niezawodność układu wymuszenia udarowego jest określona jako prawdopodobieństwo bezawaryjnej pracy - $\mathrm{tj}$. zachowania akceptowalnego stanu zdatności (bez wystąpienia istotnego uszkodzenia) elementów tego układu - w warunkach losowo zmiennych obciążeń roboczych.

Dla tak sformułowanego zadania zaproponowano metodę prognozowania niezawodności opartą na analizie losowo zmiennych obciążeń roboczych i losowo zmiennej wytrzymałości narzędzi w strefie uderzenia. Jako przykład aplikacyjny przedstawiono wyniki oceny niezawodności układów wymuszenia udarowego małogabarytowych młotów hydraulicznych przeznaczonych do wspomagania narzędzi strugów dynamicznych do urabiania cienkich pokładów węgla kamiennego. 


\section{Struktury topologiczne układów wymuszenia udarowego}

We współczesnych młotach hydraulicznych stosowane są różne rozwiązania układów wymuszenia udarowego, w ramach których można wyróżnić następujące podstawowe struktury topologiczne $[2,8]$ :

- układy o strukturze bezbijakowej (rys. 1a), w których występuje jeden element spełniający jednocześnie funkcję bijaka oraz funkcję narzędzia roboczego,

- układy o strukturze bijakowej, w których funkcje bijaka i narzędzia są rozdzielone, przy czym wyróżnia się tu układy z bezpośrednim uderzeniem typu „metal - metal” (rys. 1b) oraz układy z uderzeniem pośrednim typu „metalmedium - metal" (rys. 1c).

a)

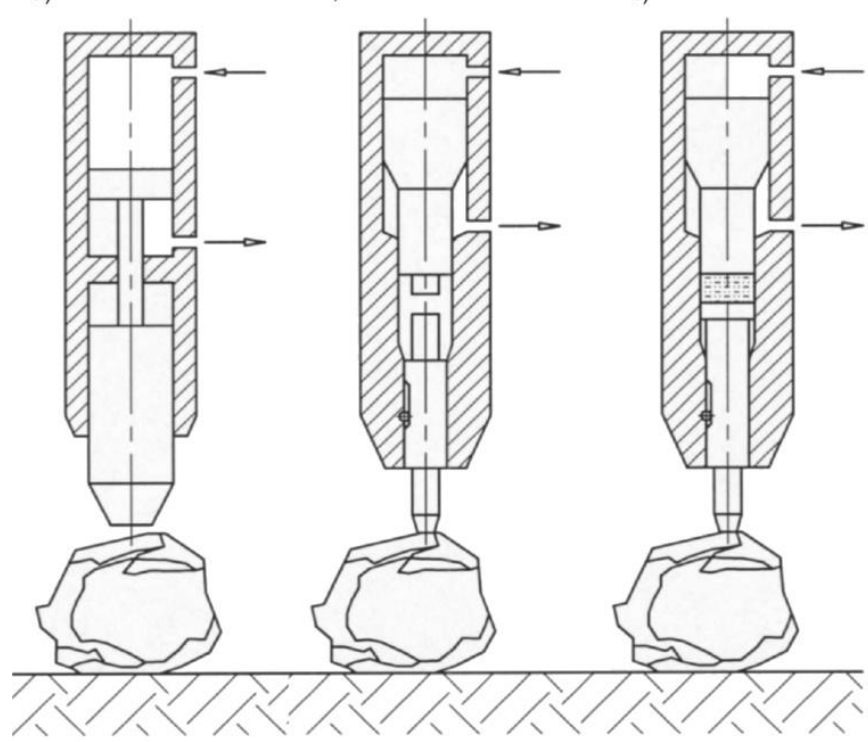

Rys. 1. Podstawowe struktury topologiczne układów wymuszenia udarowego mtotów hydraulicznych

W układach o strukturze bezbijakowej proces roboczy - np. urabianie skały, wyburzanie lub wbijanie pala fundamentowego - odbywa się poprzez bezpośrednie uderzenia narzędzia. Wprawdzie zaletą takiego rozwiązania jest możliwość stosowania dużych prędkości i energii uderzenia, to jednak istotną wadą jest fakt, że narzędzie nie jest wstępnie dociśnięte do powierzchni obiektu (np. rozbijanej bryły lub calizny skalnej). W konsekwencji tego występuje zjawisko silnego odrzutu narzędzia, co zmniejsza strumień energii użytecznej (obniża efektywność urabiania) oraz powoduje znaczne obciążenia dynamiczne układu zawieszenia młota. Z tych między innymi względów młoty $\mathrm{z}$ układami uderzeniowymi o strukturze bezbijakowej nie znajdują większego zastosowania $\mathrm{w}$ górnictwie, choć są stosowane w inżynierii lądowej - np. do usuwania nawierzchni drogowych lub wykonywania rowów i wykopów w podłożu skalistym. 
Problems of reliability assessment of impact excitation systems of hydraulic... Problemy oceny niezawodności układów wymuszenia udarowego młotów...

Istotą działania układów bijakowych bezpośredniego uderzenia (rys. 1b) jest generowanie cyklicznych uderzeń w układzie roboczym „bijak - narzędzie”, bez dodatkowych elementów pośredniczących.

Układy uderzeniowe o tej strukturze posiadają wiele zalet, wśród których szczególnie istotną cechą jest możliwość wywierania wstępnego docisku narzędzia do calizny skalnej, dzięki czemu ogranicza się niekorzystny efekt odrzutu energii uderzenia.

Układy bijakowe z dodatkowym elementem pośredniczącym - zwłaszcza te, w zastosowano medium hydrauliczne (młoty typoszeregu „HEFTI” opracowane przez Joy Mfg. Co,) - mają wiele cennych zalet. Podstawową zaletą jest możliwość stosowania dużych prędkości uderzenia (na poziomie $30 \mathrm{~m} / \mathrm{s}$ ), niedopuszczalnych w układach o konwencjonalnej strukturze bijakowej z uderzeniem bezpośrednim. Jednak mimo to układy bijakowe bezpośredniego uderzenia stanowią najobszerniejszą grupę i najczęściej stosowaną grupę układów wymuszenia udarowego w młotach hydraulicznych.

Obszerną analizę podstawowych struktur topologicznych układów wymuszenia udarowego przedstawiono w pracach $[2,8]$.

\section{Problemy badawcze}

Niezawodność układów wymuszenia udarowego traktowanych jako całość lub niezawodność poszczególnych elementów: bijaków i narzędzi może być rozpatrywana w kategoriach technicznych lub ekonomicznych.

W niniejszym artykule rozpatruje się niezawodność techniczną układu wymuszenia udarowego, która - zgodnie $\mathrm{z}$ przyjętą definicją - jest określona jako prawdopodobieństwo bezawaryjnej pracy tego układu, tj. bez wystąpienia uszkodzenia powodującego przejście ze stanu zdatności do stanu niezdatności. W tym znaczeniu niezawodność układu wymuszenia udarowego jest rozumiana jako prawdopodobieństwo zachowania właściwości użytkowych jego elementów składowych - na przykład jako prawdopodobieństwo, że wytrzymałość narzędzia nie zostanie przekroczona (nie nastąpi wykruszenie powierzchni uderzenia, pęknięcie lub wygięcie trzonu itp.).

Innym zagadnieniem - nie rozpatrywana $\mathrm{w}$ artykule - jest natomiast niezawodność formułowana $\mathrm{w}$ kategoriach ekonomicznych, która uwzględnia zagadnienia celowości i opłacalności odtwarzania stanu technicznego (naprawiania) narzędzi, w których wystąpily określone uszkodzenia.

W kontekście wieloaspektowego podejścia do niezawodności technicznej układów roboczych młotów hydraulicznych pojawia się wiele problemów badawczych, spośród których szczególne znaczenie - zdaniem autora - mają:

- identyfikacja obszarów krytycznych ze względu na degradację i uszkadzalność układów wymuszenia udarowego,

- identyfikacja struktury jakościowej i ilościowej uszkodzeń układów wymuszenia udarowego młotów hydraulicznych w warunkach polskiego górnictwa i skalnictwa, 
- estymacja rozkładów statystycznych maksymalnych wartości obciążeń (naprężeń) roboczych $\mathrm{w}$ obszarach krytycznych układów wymuszenia udarowego,

- estymacja rozkładów statystycznych podstawowych parametrów wytrzymałości elementów układów wymuszenia udarowego,

- opracowanie i doświadczalna weryfikacja metod oceny niezawodności istniejących układów wymuszenia udarowego oraz prognozowania niezawodności projektowanych układów.

\section{Czynniki wpływające na niezawodność układów wymuszenia udarowego młotów hydraulicznych}

Najczęstszymi przyczynami zawodności układów wymuszenia udarowego młotów hydraulicznych są uszkodzenia narzędzi młotów wskutek działania nadmiernych obciążeń roboczych, które - w określonych warunkach - wywołują spiętrzanie naprężeń i przekroczenie wytrzymałości doraźnej lub zmęczeniowej materiału.

Podatność na uszkodzenia narzędzi młotów jest uwarunkowana czynnikami: konstrukcyjnymi, technologicznymi i eksploatacyjnymi. Typowymi czynnikami destrukcyjnymi o charakterze konstrukcyjnym są różnego rodzaju karby konstrukcyjne (np. rowki pod sworznie mocujące narzędzia), natomiast czynnikami o podłożu technologicznym mogą być np. materiał o nieodpowiedniej strukturze lub niewłaściwa obróbka cieplno - chemiczna narzędzia.

Do podstawowych czynników destrukcyjnych o charakterze eksploatacyjnym należą między innymi [8]:

- udarowy charakter obciążeń roboczych osiągających znaczne amplitudy,

- dodatkowe, nieosiowe obciążenia zewnętrzne występujące w stanach ekstremalnych - np. podczas wykorzystywania narzędzia do podważania brył lub przy pracy pod zbyt ostrym kątem ustawienia narzędzia,

- uderzanie bijaka w narzędzie swobodne,

- ujemna temperatura powodująca obniżenie odporności na pękanie i wytrzymałości zmęczeniowej materiału narzędzia,

- korozja wskutek agresywnego oddziaływania środowiska (wilgoć, zasolenie),

- niewystarczające smarowanie powierzchni trzonu narzędzia w cylindrze młota oraz w obszarze sworzni ustalających.

Uszkodzenia narzędzi młotów mogą mieć charakter stopniowy/zużyciowy (zmęczenie, pełzanie, korozja, starzenie itp.) lub charakter nagły/katastroficzny (skrzywienie, pęknięcie lub złamanie trzonu, zatarcie, wykruszenie końcówki roboczej itp.). Niezależnie od tego, uszkodzenia mogą mieć formę:

- uszkodzeń częściowych (zniszczenie fragmentu narzędzia - np. uszkodzenie sworznia ustalającego, częściowe zużycie końcówki roboczej), przy których narzędzie może być nadal warunkowo eksploatowane $\mathrm{z}$ mniejszą efektywnością,

- uszkodzeń całkowitych (zniszczenie większego fragmentu - np. pęknięcie trzonu), kwalifikujące narzędzie do wymiany. 
Problems of reliability assessment of impact excitation systems of hydraulic... Problemy oceny niezawodności układów wymuszenia udarowego młotów...

Degradacja narzędzi młotów występuje na ogół w kilku charakterystycznych miejscach, przedstawionych na rys. 2. Typowymi formami tej degradacji są przede wszystkim: rozklepywanie powierzchni tzw. tylca (miejsca w które uderza bijak), pęknięcie trzonu, uszkodzenia sworzni ustalających, zacieranie powierzchni rowków podsworzniowych, rozklepywanie i wykruszanie końcówki roboczej $[1,8,10]$.

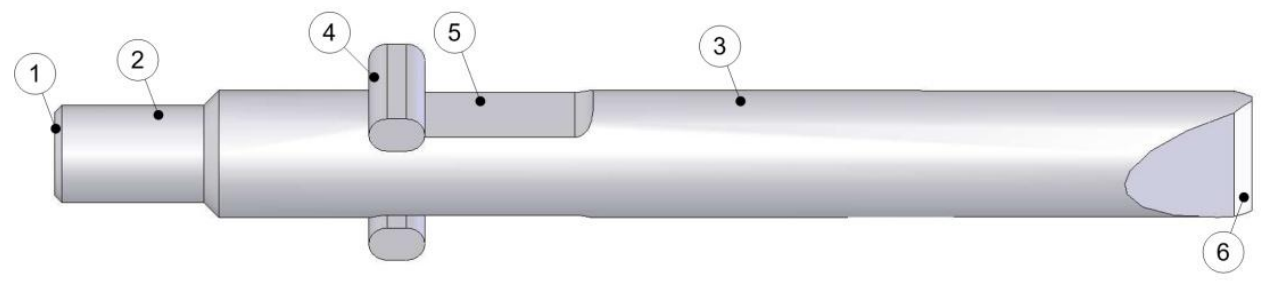

Rys. 2. Charakterystyczne obszary degradacji narzędzi mtotów hydraulicznych: 1 - strefa uderzenia, 2 -tylec, 3 -trzon, 4 -sworzeń ustalajacy, 5 - rowek podsworzniowy, 5 - końcówka robocza

Wśród czynników eksploatacyjnych wpływających na trwałość i niezawodność narzędzi szczególną rolę odgrywa właściwa obsługa techniczna obejmująca czynności profilaktyczno-zapobiegawcze (okresowe przeglądy techniczne), realizowane dla zachowania własności użytkowych młotów hydraulicznych.

Istotne znaczenie mają również kwalifikacje, doświadczenie operatorów tych urządzeń oraz indywidualne zdolności tych ludzi do dostosowania się do trudnych warunków pracy.

Jednym $\mathrm{z}$ atrybutów procesu roboczego młotów hydraulicznych jest wysoki poziom hałasu, który - zwłaszcza w ograniczonej przestrzeni (np. w wyrobisku kopalnianym) - może stanowić realne źródło zagrożeń akustycznych i powodować m. in. zaburzenia koordynacji, dekoncentrację, stres oraz szybsze męczenie się operatorów. W tych warunkach mogą zdarzać się przypadki nieprzestrzegania instrukcji obsługi młotów.

Charakterystycznymi przykładami efektów destrukcyjnego działania operatorów są uszkodzenia sworzni ustalających narzędzie (deformacje plastyczne lub lokalne pęknięcia) powstające jako efekt uderzeń bijaka w narzędzie swobodne, tj. nie kontaktujące się $\mathrm{z}$ ośrodkiem skalnym. Takie przypadki mogą zdarzać się zwłaszcza podczas urabiania twardych skał, które pod wpływem uderzeń pękają nagle, narzędzie ulega częściowemu wysunięciu aż do oparcia się na sworzniu ustalającym. Doświadczony i odpowiednio skoncentrowany operator młota jest w stanie skutecznie prognozować chwilę pęknięcia skały(na podstawie zmiany odgłosów uderzeń podczas pracy młota) i w porę wyłączyć młot. Operator niedoświadczony lub zmęczony może nie zareagować $\mathrm{w}$ porę prawidłowo i doprowadzić na przykład do uszkodzenia sworznia ustalającego narzędzie. 
Innym przykładem błędów popełnianych przez operatorów młotów jest długotrwałe uderzanie w narzędzie powyżej zalecanego okresu 20-30 sekund. Takie postępowanie generuje nadmierne wydzielanie ciepła i może powodować rozklepywanie tylca narzędzia (tzw. mushrooming). To jest na ogół kwalifikowane jako uszkodzenie nienaprawialne nawet w warunkach warsztatowych $[8,10]$.

\section{Niezawodność jako zdolność do przenoszenia obciążeń roboczych}

Niezawodność techniczna układów wymuszenia udarowego może być w szczególności określana w odniesieniu do charakterystycznych obszarów degradacji narzędzi roboczych.

Jednym z takich szczególnych obszarów krytycznych jest strefa uderzenia, w której obciążenia osiągają szczególnie duże wartości, co - przy jednoczesnej koncentracji naprężeń na powierzchni uderzenia - może stosunkowo łatwo doprowadzać do przekroczenia granicy plastyczności materiału lub nawet jego wytrzymałości. W tych okolicznościach następuje degradacja i utrata zdolności narzędzia do dalszego funkcjonowania (spełniania określonych wymagań).

Ze statycznej teorii zagadnień kontaktowych (np. na podstawie modelu Hertza) wynika, że największe wytężenie materiału w strefie styku występuje na konturze tego obszaru i jest ono większe o około 15\% niż wytężenie w środkowej strefie [3]. Analizy numeryczne procesu wymuszenia udarowego w układzie „bijaknarzędzie", przeprowadzone przez autora (m.in. $[8,9])$, wykazują, że w niektórych przypadkach wytężenie materiału w strefie uderzenia może być blisko trzykrotnie wyższe niż wynikałoby to $\mathrm{z}$ statycznej teorii zagadnienia kontaktowego Hertza. Jednak - analogicznie jak w modelu statycznym - maksymalne wytężenie występuje na konturze strefy uderzenia i jest ono przeciętnie o około $20 \%$ większe niż wytężenie w środku tej strefy.

Efektem tego jest degradacja powierzchni tylnej końcówki narzędzia przybierająca charakterystyczną formę tzw. kapelusza grzyba (ang. mushrooming) [8, 10].

W tym kontekście, ocena i prognozowanie niezawodności strefy uderzenia powinna uwzględniać fakt, że - w rzeczywistych warunkach eksploatacyjnych zarówno obciążenia robocze jak i charakterystyki wytrzymałościowe elementów układów wymuszenia udarowego są zmiennymi losowymi

Mając to na uwadze, niezawodność $R$ układu wymuszenia udarowego zdefiniowano jako prawdopodobieństwo bezawaryjnej pracy - tj. spełnienia warunku, że losowo zmienne naprężenia $\sigma \mathrm{w}$ strefie uderzenia nie przekroczą losowo zmiennej wytrzymałości $Z$ materiału narzędzia - czyli:

$$
R=P(Z>\sigma)=\int_{-\infty}^{\infty} f_{Z}(Z)\left[\int_{-\infty}^{Z} f_{\sigma}(\sigma) d \sigma\right] d Z
$$

gdzie: 
Problems of reliability assessment of impact excitation systems of hydraulic... Problemy oceny niezawodności układów wymuszenia udarowego młotów...

$\sigma, f_{\sigma}(\sigma)$ - odpowiednio: maksymalne naprężenie i funkcja gęstości rozkładu prawdopodobieństwa maksymalnych wartości naprężeń w strefie uderzenia,

$Z, f_{Z}(Z)$ - odpowiednio: wytrzymałość (nośność) i funkcja gęstości rozkładu prawdopodobieństwa wytrzymałości elementów układu wymuszenia udarowego młota

Wyrażenie (1) określa niezawodność układu wymuszenia udarowego w ujęciu „konstrukcyjnym” jako zdolność do przenoszenia obciążeń (naprężeń) roboczych z określonym, akceptowalnym prawdopodobieństwem - przy zachowaniu wymaganej wytrzymałości. Warunkiem efektywnego rozwiązania tak sformułowanego zadania badawczego jest znajomość rozkładów statystycznych maksymalnych wartości naprężeń oraz rozkładów statystycznych wytrzymałości materiału w strefie uderzenia. Przykład aplikacyjny przedstawiono poniżej.

\section{Przykład aplikacyjny - ocena niezawodności układów wymuszenia udarowego małogabarytowych mlotów hydraulicznych}

Jako przykład zastosowania proponowanej metody oceny niezawodności układów wymuszenia udarowego przytoczono wyniki badań małogabarytowych młotów hydraulicznych. Badania przeprowadzono na specjalistycznym stanowisku doświadczalnym w warunkach laboratoryjnych na Wydziale Mechanicznym Politechniki Wrocławskiej.

Obiektem badań był typoszereg małogabarytowych młotów MH1-MH7 (rys. 3) - opracowanych w CMG „Komag” w Gliwicach - przeznaczonych do wspomagania procesu roboczego strugów dynamicznych do urabiania cienkich pokładów węgla kamiennego.
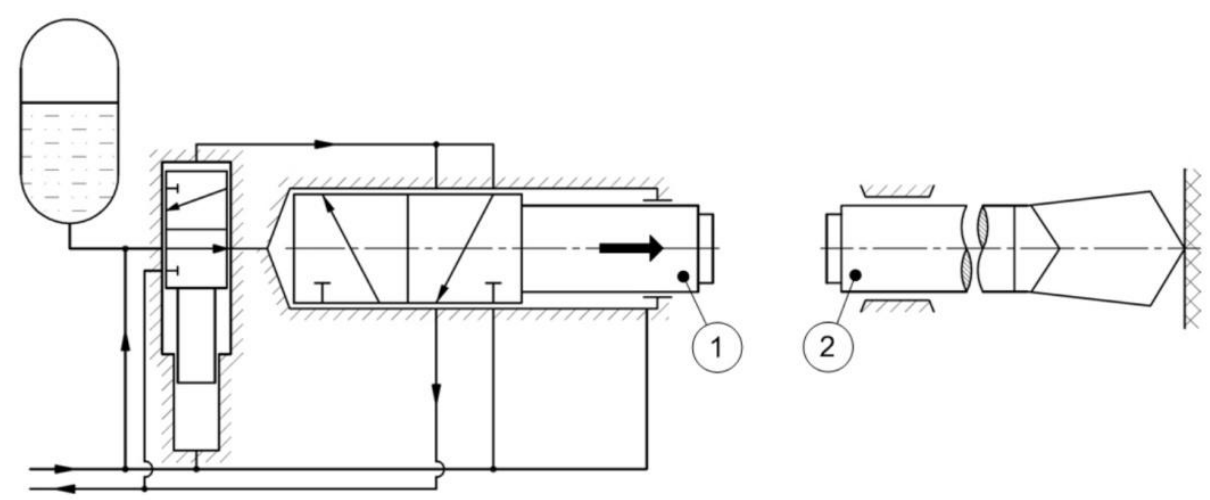

Rys. 3. Schemat matogabarytowego młota hydraulicznego: 1 - bijak, 2 -narzędzie

Badania były prowadzone dla różnych wariantów ciśnienia zasilania $p$, amplitudy swobodnego skoku bijaka $s_{\mathrm{b} 0}$ oraz pojemności akumulatorów hydraulicznych $V_{\mathrm{a}}$. wspomagających suw młotów. W toku badań rejestrowano naprężenia generowane 
w układach wymuszenia udarowego. Przykładowe histogramy maksymalnych wartości naprężeń dla 2 wariantów. tj.:

- dla nominalnych parametrów pracy młotów: $p=16 \mathrm{MPa}, V_{\mathrm{a}}=0,8 \mathrm{dm}^{3}$;

- dla ekstremalnych parametrów pracy młota: $p=20 \mathrm{MPa}, V_{\mathrm{a}}=5,0 \mathrm{dm}^{3}$;

przedstawiono na rys. 4.
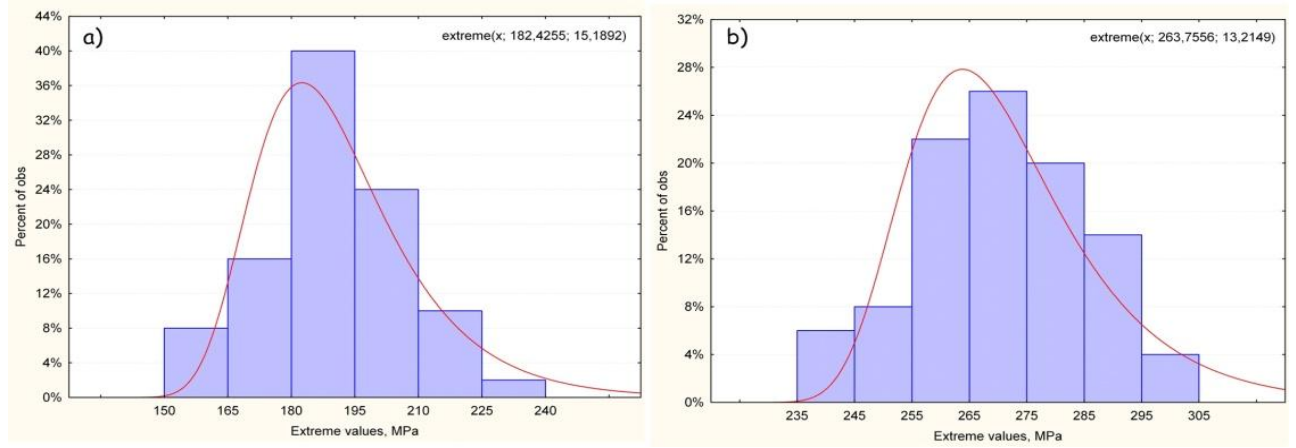

Rys. 4. Histogramy maksymalnych wartości naprężeń w strefie uderzenia: a) dla nominalnych parametrów pracy, b) dla ekstremalnych parametrów pracy

Następnie, na podstawie analizy wyników, dokonano estymacji parametrów rozkładów statystycznych wartości maksymalnych naprężeń udarowych uwzględniając trzy podstawowe rozkłady asymptotyczne: Gumbela, Frecheta oraz Weibulla. Wartości liczbowe parametrów tych rozkładów oszacowano metodą największej wiarygodności przy wykorzystaniu pakietu Statistica.

Największą zgodność rozkładów teoretycznych $\mathrm{z}$ wynikami eksperymentu uzyskano dla rozkładu Gumbela wartości maksymalnych o ogólnej postaci:

$$
f(\sigma)=f_{G}\left(\sigma_{\text {max }}\right)=\frac{1}{b} \exp \left\{-\frac{\sigma_{\text {max }}-a}{b}-\exp \left(-\frac{\sigma_{\text {max }}-a}{b}\right)\right\}
$$

gdzie: $a$ - parametr położenia, $b$ - parametr skali.

$\mathrm{W}$ odniesieniu do wytrzymałości (nośności) $Z$ elementów układu uderzeniowego przyjęto założenie, że wytrzymałość ma rozkład normalny o następujących parametrach:

- wartość oczekiwana $m_{\mathrm{Z}}$ równa granicy plastyczności $R_{\mathrm{e}}$, czyli $m_{\mathrm{Z}}=R_{\mathrm{e}}$,

- odchylenie standardowe $\mathrm{s}_{\mathrm{Z}}$ równe alternatywnie $5 \%$ lub $10 \%$ granicy plastyczności (współczynnik zmienności wytrzymałości równy odpowiednio $\delta=s_{\mathrm{Z}} / R_{\mathrm{e}}=0,05$ lub $\left.\delta=s_{\mathrm{Z}} / R_{\mathrm{e}}=0,10\right)$.

Współczynnik zmienności $\delta$ wytrzymałości uwzględnia losowe imperfekcje materiałowe oraz technologiczne (niejednorodność struktury, błędy obróbki cieplnej lub cieplno - chemicznej) oraz warunki środowiskowe (ujemna temperatura, wilgoć i zasolenie powodujące korozję itp.) wpływające na obniżenie wytrzymałości materiału. 
Problems of reliability assessment of impact excitation systems of hydraulic... Problemy oceny niezawodności układów wymuszenia udarowego młotów...

W celu uogólnienia wyników, do analizy wprowadzono współczynnik bezpieczeństwa $X=R_{\mathrm{e}} / m_{\sigma}$ zdefiniowany jako stosunek granicy plastyczności $R_{\mathrm{e}}$ do wartości oczekiwanej naprężenia $m_{\sigma}$.

$\mathrm{Na}$ tej podstawie oszacowano prawdopodobieństwo uszkodzenia $P_{\text {fail }}=P(Z<\sigma)$ oraz niezawodność $R=P(Z \geq \sigma)$ układów wymuszenia udarowego badanych młotów hydraulicznych. Przykładowe wyniki przedstawiono na rys. 5.

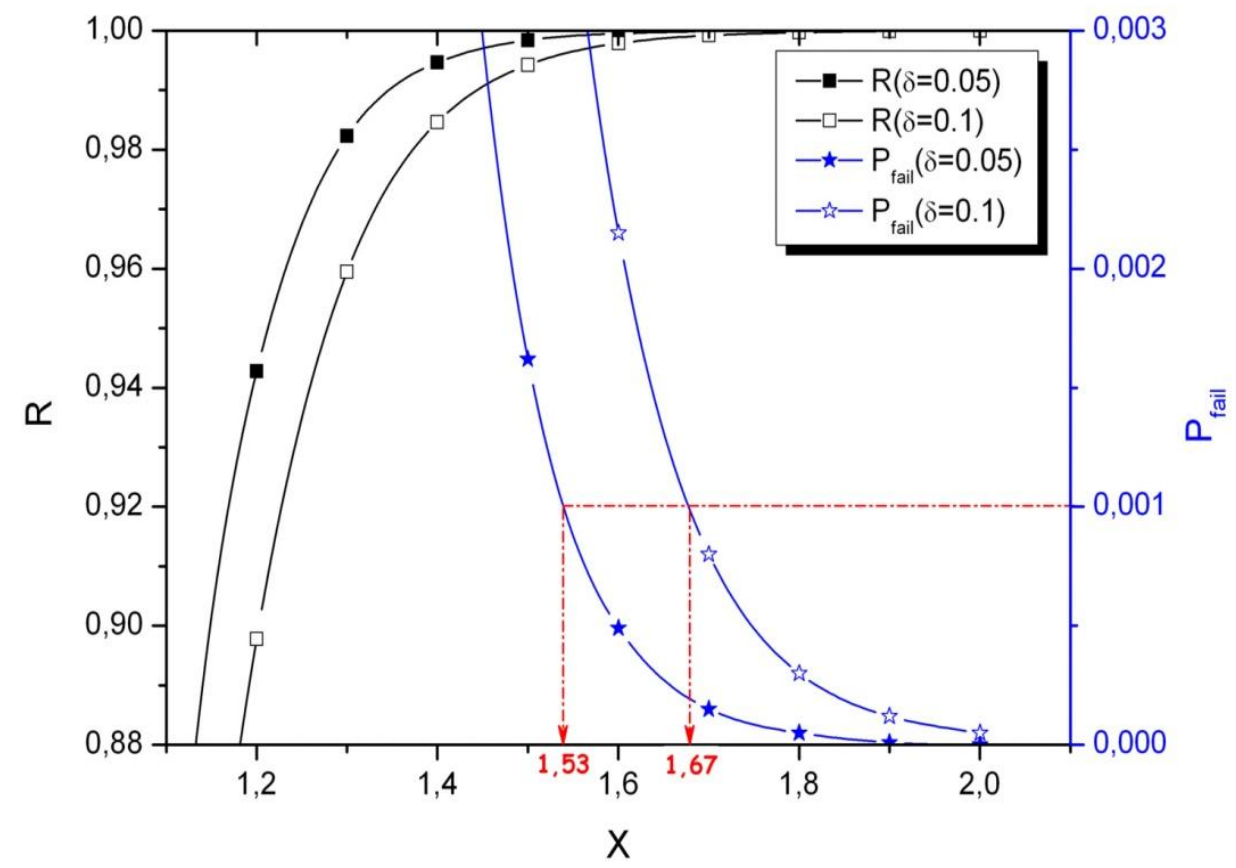

Rys. 5. Niezawodność R i prawdopodobieństwo uszkodzenia P $P_{\text {fail }}$ układów wymuszenia udarowego małogabarytowych mlotów hydraulicznych

Jeśli przyjąć, że akceptowalne prawdopodobieństwo uszkodzenia strefy uderzenia wynosi $P_{\text {fail }} \leq 0,001$, to wówczas współczynnik bezpieczeństwa odniesiony do granicy plastyczności powinien być nie mniejszy niż $X_{\min }=1,5 \div 1,7$ (rys. 5). Większe wartości wymaganego współczynnika bezpieczeństwa $X_{\min }$ odnoszą się do przypadków stali wykazujących większy rozrzut granicy plastyczności (współczynnik zmienności $\delta=s_{\mathrm{z}} / R_{\mathrm{e}}=0,10$ ).

Jeśli przyjąć jako warunek bezawaryjnej pracy układu wymuszenia udarowego prawdopodobieństwo $\mathrm{P}_{\text {fail }} \leq 0,01$ oraz niezawodność na poziomie $R \geq 0,99$, to:

- Dla nominalnych parametrów pracy badanych młotów: elementy układów wymuszenia udarowego powinny być wykonane ze stali o granicy plastyczności nie mniejszej niż (uwzględniając parametry rozkładu Gumbela wartości maksymalnych naprężeń - rys. 4a):

$$
R_{\mathrm{e}(\min )} \geq X_{\min } \cdot m_{\sigma} \cong(1,5 \div 1,7) \cdot 191,2 \cong 270 \div 235 \mathrm{MPa} .
$$


- Dla ekstremalnych parametrów pracy badanych młotów: elementy układów wymuszenia udarowego powinny być wykonane ze stali o granicy plastyczności nie mniejszej niż (uwzględniając parametry rozkładu Gumbela wartości maksymalnych naprężeń - rys. 4b):

$$
R_{\mathrm{e}(\min )} \geq X_{\min } \cdot m_{\sigma} \cong(1,5 \div 1,7) \cdot 271,4 \cong 410 \div 460 \mathrm{MPa} .
$$

W powyższych obliczeniach uwzględniono, że wartość oczekiwana $m_{\sigma}$ rozkładu Gumbela wartości maksymalnych jest równa $m_{\sigma}=a+\gamma \cdot b \cong a+0,577 \cdot b$ (gdzie: a, b - parametry rozkładu Gumbela, $\gamma$ - stała Eulera).

\section{Podsumowanie}

Niezawodność układów wymuszenia udarowego młotów hydraulicznych jest uwarunkowana różnorodnymi czynnikami konstrukcyjnymi, technologicznymi i eksploatacyjnymi.

Prezentowana metoda prognozowania niezawodności opiera się na ocenie zdolności układów „bijak - narzędzie” do przenoszenia obciążeń roboczych - przy zachowaniu niezbędnego zapasu bezpieczeństwa konstrukcji. W metodzie uwzględnia się losowy charakter naprężeń udarowych oraz losowy charakter wytrzymałości elementów tych układów. Parametry rozkładów statystycznych tych wielkości są wyznaczane doświadczalnie.

Jako przykład aplikacyjny przedstawiono ocenę niezawodności układów wymuszenia udarowego małogabarytowych młotów hydraulicznych przeznaczonych do wspomagania procesu roboczego węglowych strugów dynamicznych.

\section{Literatura}

[1] Bauer E.E.: Contech Mining Application Manual. Consolidated Technologies Corp., Mining Division, Denver (sine anno).

[2] Grantmyre I., Hawkes I., High - Energy Impact Rockbreaking, The Canadian Mining and Metallurgical Bulletin. August 1975, 1-8.

[3] Johnson K.L: Contact Mechanics, Cambridge University Press, Cambridge, 2003.

[4] Kececioglu D.: Reliability Engineering Handbook, vol. 1, DEStech Publications, Inc., Lancaster, PA, USA, 2002.

[5] Migdalski J. (red.): Poradnik niezawodności. Podstawy matematyczne. Wyd. „WEMA”, Warszawa 1982.

[6] Nowakowski T.: Niezawodność systemów logistycznych. Oficyna Wydawnicza Politechniki Wrocławskiej, Wrocław, 2011.

[7] Smalko Z.: Selected problems of description and estimation of durability. Journal of KONBiN 1(4) 2008, s. 321-326. 
Problems of reliability assessment of impact excitation systems of hydraulic... Problemy oceny niezawodności układów wymuszenia udarowego młotów...

[8] Sokolski M.: Podstawy syntezy charakterystyk młotów hydraulicznych, Oficyna Wydawnicza Politechniki Wrocławskiej, Wrocław, 2013.

[9] Sokolski M., Sokolski P.M.: Strength estimation of the impact zone - a critical area of the tools of the hydraulic hammers. Archives of Civil and Mechanical Engineering, 2016, vol. 16, $\mathrm{nr}$ 4, s. 767-776.

[10] TB Series Hydraulic Breakers. Owner's Manual. Breaker Technology Inc., Thornbury, ON, Canada 2013.

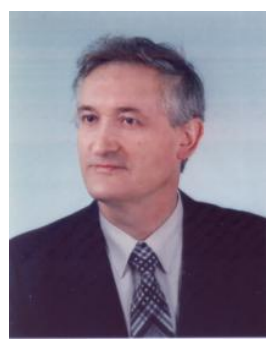

Dr hab. ini. Marek Sokolski, Politechnika Wroctawska, Wydziat Mechaniczny, Katedra Eksploatacji Systemów Logistycznych, Systemów Transportowych i Uktadów Hydraulicznych. Praca doktorska dotyczyła zagadnień identyfikacji charakterystyk energetyczno-silowych $w$ procesie urabiania skat zwięztych Rozprawa habilitacyjna dotyczyla podstaw syntezy charakterystyk mlotów hydraulicznych. Obszary zainteresowań: maszyny robocze $i$ górnicze, infrastruktura systemów magazynowych, transport wewnętrzny, diagnostyka techniczna, niezawodność. 